\title{
Study of Schistosoma mansoni Isolates from Patients with Failure of Treatment with Oxamniquine
}

\author{
Maria José Conceição/ ${ }^{+}$, Carlos Alberto Argento*, Acyr Corrêa**
}

\begin{abstract}
Serviço de Doenças Infecciosas e Parasitárias, Departamento de Medicina Preventiva, Hospital Universitário Clementino Fraga Filho *Serviço de Doenças Infecciosas e Parasitárias, Faculdade de Medicina, Universidade Federal do Rio de Janeiro, Avenida Brigadeiro Trompowsky s $/ \mathrm{n}^{\circ}$, Cidade Universitária, Ilha do Governador 21941-590, Rio de Janeiro, RJ, Brasil ** Departamento de Medicina Tropical, Instituto Oswaldo Cruz, Av. Brasil 4365, 21045-900 Rio de Janeiro, RJ, Brasil
\end{abstract}

\begin{abstract}
After three successive treatments with oxamniquine the continuing elimination of Schistosoma mansoni eggs was observed in patients, who came from various regions of Brazil, with different clinical forms of schistosomiasis. The objective of the present study was to determine the experimental behaviour of five different S. mansoni isolates in Swiss Webster mice that were submitted to treatment with the same drug. The experimental group with failure of treatment showed higher mean number of surviving male worms when it was compared to the group without failure of treatment. These date suggest the possibility of resistance to oxamniquine.
\end{abstract}

Key words: Schistosoma mansoni - patients - oxamniquine - failure of treatment

Foster et al. (1971 a,b) and Pellegrino and Katz (1972), reported promising schistosomicidal activity for oxamniquine. Pica-Mattoccia and Cioli (1985), emphasized that a single oral dose is usually effective, immediate toxicity is low and general side effects are weak or absent. Its biochemical mechanisms is related to an anticholinergic effect which increases the parasite's motility (Hillman \& Senft 1975), as well as to synthesis inhibition of nucleic acids (Pica-Mattoccia et al. 1989). Bina (1977, 1995), in endemic areas of Bahia, stressed the effects of specific treatment, mainly with oxamniquine, plus environmental modification involving the prevention and reversibility of the hepatosplenic form of schistosomiasis. Andrade (1998) presented important new data on this subject. In Brazil, Katz (1980) revealed a cure index with the drug of 80 to $98 \%$ for adults and 60 to $90 \%$ for children. Lambertucci et al. (1990) obtained a lower cure index of children treated in the acute phase $(45 \%)$. Foster and Cheetam (1973) reported the possibility of a variation in the response to the drug according to the geographic origin of the parasite. Clarke et al.

This work was partially supported by Capes and Conselho Nacional de Desenvolvimento Científico e Tecnológico, CNPq.

${ }^{+}$Corresponding author. Fax: +55-21-280.3740.

Email:conceicao@ioc.fiocruz.br

Received 19 April 1999

Accepted 7 December 1999
(1976) detected a lower cure index in some African countries in which oxamniquine has been used at much higher doses. Coles et al. (1987) described tolerance by Kenyan isolates of Schistosoma mansoni treated with this drug.

Pioneering clinical studies in Brazil (Katz et al. 1973) have approached the topic of resistance of $S$. mansoni isolates to oxamniquine. Jansma et al. (1977) induced resistance experimentally. Araujo et al. (1980) compared several S. mansoni isolates from patients in the State of Minas Gerais and detected variations in the response to the drug. Dias et al. (1982) refered to the use of praziquantel in patients with oxamniquine and hycanthone resistant S. mansoni. According to Cioli et al. (1989) genetic crosses between phenotypically resistant and sensitive schistosomes demonstrated that resistance to hycanthone and oxamniquine behaves like a resistant trait, thus suggesting that resistance is due to the lack of a bioactivation process, maybe owing to a specific enzyma that promotes the schistosomicide effect of the drug (Coelho et al. 1997). Doenhoff and Bain (1978) showed the involvement of immune mechanisms in drug induced killing of adult worms (antimonial). Doenhoff et al. (1987) concluded that the duration of infection and infection intensities affect the outcome of chemotherapy. Also, Doenhoff (1987) indicated that immune effector mechanisms can enhance the activity of schistosomicidal drugs. Praziquantel, oxamniquine, hycanthone and antimony were shown to be less effective against $S$. mansoni infection in mice immunosuppressed by $\mathrm{T}$ cell deprivation than against comparable infec- 
tion in normal mice.The results obtained for Drescher et al. (1993) confirmed the resistance of S. mansoni isolates to niridazole, oxamniquine and hycanthone, although all isolates were susceptible to praziquantel. Coelho et al. (1997) isolated from patient treated four times with oxamniquine a resistant strain of $S$. mansoni (R1). Coelho et al. (1998) showed that resistance recorded could not be detected in schistosomules at the skin and pulmonary phases, but in females, at the sexual maturation phase.

Variation in response to the drug was also observed at the outpatient clinic of the Serviço de Doenças Infecciosas e Parasitárias (Conceição et al. 1995, 1997) and motivated the present experimental study examining isolates of the parasite that did not respond to oxamniquine.

\section{PATIENTS AND METHODS}

In relation to the clinical form recorded for 954 S. mansoni infected patients, $572(59.9 \%)$ presented the schistosomiasis infection form (Type I), 298 (31.2\%) the hepatointestinal form (Type II), and $68(7.1 \%)$ the hepatosplenic form (Type III); one case progressed to schistosomotic pulmonary hypertension and another developed infantilism (deficient somatic and sexual development). Sixteen others cases $(1.6 \%)$ presented the toxemic form of the disease.

Fecal examination was performed by the method of Kato (1960) modified by Katz et al. (1972). The clinical forms of schistosomiasis were determined according to the classification of Pessoa and Barros (1953), modified by Barbosa (1966). Based on a random selection the patients were treated with a single oral dose of oxamniquine (15 $\mathrm{mg} / \mathrm{kg}$ ), or praziquantel $(40 \mathrm{mg} / \mathrm{kg}$ ).

Five $S$. mansoni strains were isolated from patients who continued to eliminate parasite eggs after three consecutive treatments with oxamniquine and did not present any evidence of reinfection. All patients reported chronical schistosomiasis and there was no clinical data or serological tests that had shown immunologically impairment. It was not possible to obtain isolates in cases in which there was a diagnosis of viable eggs by the rectal biopsy. The patients selected (Table I) delivered containers with their feces to the Hospital Universitário Clementino Fraga Filho, and the material was immediately transported to the Laboratory of the Department of Tropical Medicine, Oswaldo Cruz Institute, Rio de Janeiro, Brazil. The isolates were maintained in sucessive generations in mice and snails until the begining of the experimental treatment.

Each S. mansoni isolate was obtained by successive sedimentation of fecal material and there- after placed in a Chaia bottle for miracidium hatching (Chaia 1956). Forty Biomphalaria glabrata snails were individually infected with five miracidia from each of the five strains. The mollusks were from the rural area of Capitão Andrade, Minas Gerais, and had been reared under laboratory conditions since 1979. After 30 days, the mollusks were examined to determine the rates of infection. A pool of mollusks presenting cercaria emergence was formed. Fifty cercariae were quantified for infection by the percutaneous (caudal) route of each of 60 male albino mice aged 21 days and weighing 11 to 16 grams (Conceição \& Coura 1986). Thirty of the 60 mice infected with $S$. mansoni from each of the five patients who presented "failure of treatment" to oxamniquine (denoted isolates Hospital Universitário 1, 2, 3, 4 and 5) were treated with oxamniquine at a dose of $100 \mathrm{mg} / \mathrm{kg}$ body weight on the 50th day post-infection using a tube adapted in the laboratory. On the 14th day post-treatment the animals were submitted to perfusion of the portal system and the worms were counted in the liver and mesentery using the technique of Radke et al. (1961), in order to determine the number of live worms recovered. The remaining 30 animals (out of a total of 60) were not treated with oxamniquine and were used as controls (isolates HU 1c, 2c, 3c, 4c and 5c). The therapeutic value of the drug was evaluated using the equation of Kemp et al. (1956): $\frac{a-b}{a} \times 100=$ efficacy where a: mean number of live worms recovered from untreated animals, and $\mathrm{b}$ : mean number of live worms recovered from treated animals.

\section{TABLE I}

Distribution of patients with and without failure of treatment to oxamniquine according age, sex, areas of origin and clinical form

\begin{tabular}{lcclc}
\hline $\begin{array}{l}\text { Patients } \\
\text { identification }\end{array}$ & Age & Sex & Areas of \\
(F/M) & origin & $\begin{array}{c}\text { Clinical } \\
\text { form } \\
\text { (Type) }\end{array}$ \\
\hline
\end{tabular}

\begin{tabular}{lcclc}
\hline With failure & & & & \\
R.S. & 35 & F & Minas Gerais & II \\
E.M.S. & 26 & F & Minas Gerais & II \\
M.J.B. & 37 & F & Minas Gerais & I \\
J.V. & 14 & M & Bahia & I \\
V.M. & 22 & M & Paraíba & I \\
Without failure & & & & \\
M.R.S. & 28 & F & Bahia & II \\
T.R. & 24 & F & Bahia & I \\
L.C.D. & 13 & M & Minas Gerais & III \\
D.E. & 31 & M & Minas Gerais & II \\
O.N. & 34 & M & Paraíba & I \\
\hline
\end{tabular}

Type I: schistosomiasis infection; Type II: hepatointestinal; Type III: hepatosplenic; F: female; M: male 
We also selected five $S$. mansoni isolates from patients who responded to oxamniquine. The eggs for hatching of miracidia were obtained before treatment. Sixty mice were infected with each isolate. Thirty animals (denoted isolates HU 6, 7, 8, 9 and 10) were submitted to treatment with oxamniquine $(100 \mathrm{mg} / \mathrm{kg}$ body weight by the oral route) on the 50th day after infection. On the 14th day post-infection, the animals were submitted to perfusion of the portal system and the worms were counted in the liver and mesentery by the technique of Radke et al. (1961). The 30 remaining mice out of a total of 60 were not treated and formed the control group (Hospital Universitário $6 \mathrm{c}, 7 \mathrm{c}, 8 \mathrm{c}$, $9 \mathrm{c}$, and $10 \mathrm{c})$.

Statistical analysis were performed: (1) by the Analysis of Variance of Kruskal-Wallis to compare the mean number of recovered worms among the four groups: (a) experimental group-treated miceisolates with failure of treatment; (b) experimental group without failure of treatment; (c) control group with failure of treatment; (d) control without failure of treatment. The test of Multiple Comparisons based on the statistic of Kruskal-Wallis aiming determine which inter group differences; (2) Wilcoxon Signed Rank test to compare the mean number of male and female worms separately for each group.

The p-value was significant at the 0,05 level. Statistical analysis were performed using Statistical Applications Software (SAS, Cary, NC, USA).

\section{RESULTS}

Among the patients treated with oxamniquine, $10.3 \%$ continued to eliminate $S$. mansoni eggs even after being submitted to three consecutive treatments with the drug, as determined by the method of Kato modified by Katz et al. (1972) and/or by rectal biopsy.

In this study comparing the possibility of cure of schistosomiasis infection with oxamniquine and praziquantel, no case of a S. mansoni isolate with resistance to praziquantel was observed. All patients responded to this medication, however, Ismail et al. (1995) revealed praziquantel resistance in Egypt. The side effects of both drugs occurred at low percentages and were similar.

The five $S$. mansoni isolates obtained from patients with lack of response to oxamniquine behaved in mice as indicated in Table II.

The isolates, denoted HU 1, 2, 3, 4 and 5, were maintained in 30 mice which were treated with oxamniquine. Acidental death of some mice occurred at the time of introduction of the esophageal tube used for treatment. These isolates were compared to those maintained in untreated animals (denoted isolates Hospital Universitário 1c, 2c, 3c, $4 \mathrm{c}$ and $5 \mathrm{c})$. Mean (+ SD) recovery of live worms from treated animals ranged from $4+0.4$ to $6+$ 1.9. In the control group of untreated animals, the recovery of live worms ranged from $24+8.3$ to 30 +9.4 . The efficacy of treatment with oxamniquine ranged from $72.4 \%$ to $83.3 \%$ (Table II).

Table III summarizes the results obtained with the five $S$. mansoni isolates from patients who responded to treatment with oxamniquine in mice submitted to treatment with the same drug (Experimental Group, Isolates Hospital Universitário 6, 7, 8, 9 and 10). These same isolates were maintained in mice not treated with the drug (Control Group, denoted Isolates HU 6c, 7c, 8c, 9c and $10 \mathrm{c})$. The mean $(+\mathrm{SD})$ number of live worms recovered from the Study Group ranged from $2+02$ to $3+0.6$ and that recovered from the Control Group ranged from $29+6.9$ to $30+8.3$. The efficacy of treatment with oxamniquine in this group, in which the isolates originated from patients who respond to the drug, ranged from $88.3 \%$ to $92.8 \%$.

In the Table IV is shown the mean number of male, female and total worms from patients with failure and without failure of treatment with oxamniquine, and the equivalent data from the

\section{TABLE II}

Efficacy of oxamniquine in isolates of Schistosoma mansoni from patients with failure of treatment to the drug, after perfusion in treated and untreated Swiss Webster mice

\begin{tabular}{|c|c|c|c|c|c|c|c|c|}
\hline \multicolumn{4}{|c|}{ Experimental group (treated mice) } & \multicolumn{5}{|c|}{ Control (untreated mice) } \\
\hline $\begin{array}{l}\text { Isolates } \\
\mathrm{HU}\end{array}$ & $\begin{array}{l}\text { No. of } \\
\text { mice }\end{array}$ & $\begin{array}{l}\text { No. of worms } \\
\text { live recoverd }\end{array}$ & SD & $\begin{array}{c}\text { Isolates } \\
\text { HU }\end{array}$ & $\begin{array}{l}\text { No. of } \\
\text { mice }\end{array}$ & $\begin{array}{l}\text { No. of worms } \\
\text { live recovered }\end{array}$ & SD & Efficacy \\
\hline 1 & 30 & 5 & \pm 1.1 & $1 \mathrm{c}$ & 30 & 30 & \pm 9.2 & 83.3 \\
\hline 2 & 28 & 6 & \pm 1.9 & $2 c$ & 29 & 30 & \pm 9.4 & 80.0 \\
\hline 3 & 29 & 8 & \pm 0.8 & $3 c$ & 30 & 29 & \pm 8.9 & 72.4 \\
\hline 4 & 28 & 6 & \pm 1.4 & $4 c$ & 28 & 26 & \pm 8.7 & 76.9 \\
\hline 5 & 29 & 4 & \pm 0.4 & $5 c$ & 30 & 24 & \pm 8.3 & 83.3 \\
\hline
\end{tabular}

SD: standard deviation; HU: Hospital Universitário Clementino Fraga Filho 
TABLE III

Efficacy of oxamniquine in isolates of Schistosoma mansoni, from patients without failure of treatment to the drug, after perfusion in treated and untreated Swiss Webster mice

\begin{tabular}{|c|c|c|c|c|c|c|c|c|}
\hline \multicolumn{4}{|c|}{ Experimental group (treated mice) } & \multicolumn{5}{|c|}{ Control (untreated mice) } \\
\hline $\begin{array}{l}\text { Isolates } \\
\mathrm{HU}\end{array}$ & $\begin{array}{l}\text { No. of } \\
\text { mice }\end{array}$ & $\begin{array}{l}\text { No. of worms } \\
\text { live recoverd }\end{array}$ & SD & $\begin{array}{c}\text { Isolates } \\
\mathrm{HU}\end{array}$ & $\begin{array}{c}\text { No. of } \\
\text { mice }\end{array}$ & $\begin{array}{l}\text { No. of worms } \\
\text { live recovered }\end{array}$ & SD & Efficacy \\
\hline 6 & 26 & 2 & \pm 0.3 & $6 c$ & 29 & 27,9 & \pm 8.3 & 92.8 \\
\hline 7 & 24 & 2 & \pm 0.2 & $7 \mathrm{c}$ & 30 & 27 & \pm 8.1 & 92.6 \\
\hline 8 & 28 & 3 & \pm 0.5 & $8 c$ & 29 & 26 & \pm 7.9 & 88.5 \\
\hline 9 & 28 & 2 & \pm 0.3 & $9 \mathrm{c}$ & 29 & 25 & \pm 6.9 & 92.2 \\
\hline 10 & 29 & 3 & $\pm 0,4$ & $10 \mathrm{c}$ & 30 & 24 & \pm 8.3 & 88.3 \\
\hline
\end{tabular}

SD: standard deviation; HU: Hospital Universitário Clementino Fraga Filho

TABLE IV

Comparative study of the mean number of male and female Schistosoma mansoni, from patients with failure and without failure of treatment with oxamniquine, after perfusion in treated and untreated Swiss Webster mice

\begin{tabular}{|c|c|c|c|c|}
\hline \multirow{3}{*}{$\begin{array}{l}\text { Sex } \\
\text { of } \\
\text { worm }\end{array}$} & \multicolumn{2}{|c|}{ Experimental group (treated mice) } & \multicolumn{2}{|c|}{ Control group (untreated mice) } \\
\hline & $\begin{array}{c}\text { With failure } \\
\quad(\mathrm{n}=144)\end{array}$ & $\begin{array}{l}\text { Without failure } \\
\qquad(\mathrm{n}=136)\end{array}$ & $\begin{array}{l}\text { With failure } \\
\quad(n=146)\end{array}$ & $\begin{array}{l}\text { Without failure } \\
\qquad(\mathrm{n}=145)\end{array}$ \\
\hline & Mean SD & Mean SD & Mean SD & Mean SD \\
\hline Male & $3.09 \pm 1.30$ & $1.35 \pm 0.90$ & $14.28 \pm 3.33$ & $13.94 \pm 3.58$ \\
\hline Female & $2.72 \pm 1.30$ & $1.28 \pm 0.92$ & $13.94 \pm 3.24$ & $13.96 \pm 3.91$ \\
\hline Total & $5.81 \pm 1.83$ & $2.63 \pm 1.40$ & $28.22 \pm 5.652$ & $7.91 \pm 6.85$ \\
\hline
\end{tabular}

SD: standard deviation

control groups with and without failure. There was a significant difference in the number of male worms detected in the four groups $(p=0.0001)$. The experimental groups were significantly different and showed differences in relation to the control groups. The control groups did not reveal any significant difference. The same was observed between females and total worms.

A comparison of the mean number of males and female in the groups with failure of treatment, revealed a significative difference $(\mathrm{p}=0.001)$, with a higher mean number of male worms recovered than female worms. However, there was no difference: (a) in the experimental group without failure $(\mathrm{p}=0.58) ;(\mathrm{b})$ in the control group with failure $(\mathrm{p}$ $=0.21)$; or $(\mathrm{c})$ in the control group without failure $(\mathrm{p}=0.77)$.

\section{DISCUSSION}

When the experimental results concerning the efficacy of treatment with oxamniquine against $S$. mansoni isolates obtained from patients who did not respond to the drug were compared, a variation from $72.4 \%$ to $83.3 \%$ was observed, indicating that the isolates were susceptible to the drug (mean efficacy of 79.7\%). The present results ob- tained for animals inoculated with S. mansoni isolates from patients with failure to oxamniquine did not confirm the probable resistance observed by Katz et al. (1973) using a human strain of the parasite resistant to oxamniquine and to other schistosomicidal agents. Araújo et al. (1980), Dias et al. (1978, 1982), Meang et al. (1987), Bruce et al. (1987), emphasized similar results with Brazilian isolates from Minas Gerais. Kinoti (1987) reported variations in the suscetibility of $S$. mansoni to oxamniquine within certain areas of Brazil and Kenya. In our study we recovered five $S$. mansoni isolates from patients from Minas Gerais, Bahia and Paraíba who did not respond to the drug. It was not possible to obtain isolates from the same area, because in these cases the viable eggs were diagnosed by rectal biopsy. Kaye, quoted by Foster (1987) did not suggest differences in the pharmacokinetics of the drug to explain the variation in susceptibility, in a study with patients from Tanzania, South Africa and Brazil since he found similar concentrations of the drug in all blood samples.

The five $S$. mansoni isolates selected from patients who did not respond to the drug showed an efficacy of experimental treatment of approximately $80 \%$ after a single dose of $100 \mathrm{mg} / \mathrm{kg}$ body 
weight. The mean number of male worms recovered from the experimental group with failure of treatment with oxamniquine was higher than in the experimental group without failure of treatment. The analysis into the groups with failure of treatment revealed higher number of males surviving in the isolate $\mathrm{HU} 3$, which denotes a possible resistance to the drug in that isolate corroborating the previous results of Coelho et al. (1997). The study is being continued in order to determine the genomic denomination of the DNA of these $S$. mansoni isolates and to compare it with that of parasite isolates recovered from patients who responded to treatment with oxamniquine. We intend to characterize the parasite strains at the molecular biochemical level to clarify the factor(s) responsible for the absence of cure in patients infected with Schistosoma even after repeated treatment with oxamniquine.

\section{ACKNOWLEDGMENT}

To Dr Norton Figueiredo, in memorian, who helped us to start this research, to Dr Naftale Katz, from Centro de Pesquisas Rene Rachou, Belo Horizonte, MG, for revision of the manuscript and for encouragement, to $\mathrm{Dr}$ J Rodrigues Coura for the facilities at the Departamento de Medicina Tropical, Fiocruz, Rio de Janeiro. To Raquel Callegario Gomes and Rosangela Aparecida Noé, from Comissão de Investigação Científica (CIC) - HUCFFUFRJ, for the statistical analysis and to Haroldo Luiz Saback de Macedo from CIC-HUCFF-UFRJ, for the suggestions.

\section{REFERENCES}

Andrade ZA 1998. The situation of hepatosplenic schistosomiasis in Brazil today. Mem Inst Oswaldo Cruz. 93: 313-316.

Araújo N, Katz N, Dias CP, Souza CP 1980. Susceptibility of chemotherapeutic agents of strains of Schistosoma mansoni, isolated from treated and untreated patients. Am J Trop Med Hyg 29: 890-894.

Barbosa FAS 1966. Morbidade da esquistossomose. Rev Bras Malariol D Trop, Special issue: 3-153.

Bina JC 1977. Influência da Terapêutica Específica na Evolução da Esquistossomose, MSc Thesis, Universidade Federal da Bahia, Salvador, 58 pp.

Bina JC 1995. Estudo das Variáveis que Podem Influenciar na Evolução da Esquistossomose Mansônica: Efeito da Terapêutica Específica e da Interrupção da Transmissão, $\mathrm{PhD}$ Thesis, Universidade Federal da Bahia, Salvador, $126 \mathrm{pp}$.

Bruce JL, Dias LCS, Liang Y, Coles GC 1987. Drug resistance in schistosomiasis: A review. Mem Inst Oswaldo Cruz 82 (Suppl. IV): 143-150.

Chaia G 1956.Técnica para concentração de miracídios. Rev Bras Malariol D Trop 8: 355-377.

Cioli D, Pica-Mattoccia L, Archer S 1989. Resistance of schistosomes to hycanthone and oxamniquine. Mem Inst Oswaldo Cruz 84 (Suppl. I): 38-44.

Cioli D, Pica-Mattoccia L, Moroni R 1992. Hycanthone/
Oxamniquine resistance is controlled by a single autosomal recessive gene. Exp Parasitol 75: 425432.

Clarke VV, Blair DM, Weber MC, Garnett PA 1976. Dose-finding trials of oral oxamniquine in Rhodesia. South Af Med J 50: 1867-1871.

Coelho PMZ, Ribeiro F, Mello RT, Silva FCL, NogueiraMachado JA 1998. Activity of oxamniquine at skin, pulmonary and sexual maturation phases, on a Schistosoma mansoni strain (R1) previously reported as resistant at the adult phase. Mem Inst Oswaldo Cruz 93 (Suppl. I): 267-268.

Coelho PMZ, Silva ECL, Nogueira-Machado JÁ 1997. Resistance to oxamniquine of a Schistosma mansoni strain isolated from patient submitted to repeated treatments. Rev Inst Med Trop S Paulo 39 : 101-106

Coles GC, Mutahi WT, Kinoti GK, Bruce J I, Katz N 1987. Tolerance of Kenyan Schistosoma mansoni to oxamniquine. Trans R Soc Trop Med Hyg 81: 782785.

Conceição MJ, Coura J R 1986. Comportamento experimental de amostras de Schistosoma mansoni em relação às formas clínicas de esquistossomose. I. Estudo em camundongos. Mem Inst Oswaldo Cruz 81: 61-66.

Conceição MJ, Argento CA, Moura DC, Silva SC 1997. Estudo experimental de isolados de Schistosoma mansoni de pacientes que não obtiveram cura com a oxamniquine. Rev Soc Bras Med Trop 30: 117.

Conceição MJ, Argento CA, Teixeira A 1995. Tolerance to oxamniquine in Schistosoma mansoni infected patients. Abstracts International Conference on Schistosomiasis, Cairo, Egypt, p. 167.

Dias LCS, Pedro RJ, Duberaldine ER 1982. Use of praziquantel in patients with schistosomiasis mansoni previously treated with oxamniquine and/or/ hycanthone of Schistosoma mansoni to schistosomicidal agents. Trans R Soc Trop Med Hyg 76: 652659.

Dias LCS, Pedro RJ, Rigo E, Goto MF, Mafra GK 1978 Linhagem humana de Schistosoma mansoni resistente a esquistosomicidas. Rev Saúde Pública 12: 110 .

Doenhoff M J 1987. The immune dependence of chemotherapy in experimental schistosomiasis. $\mathrm{Mem}$ Inst Oswaldo Cruz 84 (Suppl. I): 31-37.

Doenhoff MJ, Bain J 1978. The immune-dependence of schistosomiasis chemotherapy relative lack of efficacy of an antimonial in Schistosoma mansoniinfected mice deprived of their T-cells and the demonstration of drug- antiserum synergy. Clin Exp Immununol 33: 232-238.

Doenhoff M J, Sabah AAA, Fletcher C, Webbe G, Bain J 1987. Evidence for an immuno-dependent action of praziquantel on Schistosoma mansoni in mice. Trans $R$ Soc Trop Med Hyg 81: 947-951.

Drescher KM Rogers EJ, Bruce JI, Katz N, Dias LCS, Coles G 1993. Response of drug resistant isolates of Schistosoma mansoni to antischistosomal agents. Mem Inst Oswaldo Cruz 88: 89-95.

Foster R 1987. A review of clinical experience with oxamniquine. Trans $R$ Soc Trop Med Hyg 81: 55-59. 
Foster R, Cheetam BL 1973. Studies with schistosomicide oxamniquine (UK-427A). I. Activity in rodents and in vitro. Trans $R$ Soc Trop Med Hyg 67: 674-684.

Foster R, Cheetam RL, King DF, Mesmer ET 1971a. The action of UK 3883, a novel, 2-aminomethyltetrahydroquinoline derivative, against mature schistosomes in rodents and primates. Ann Trop Med Parasitol 65: 59-70.

Foster R, Cheetam RL, Mesmer ET, King DF 1971b. Comparative studies of the action of mirasan, lucanthone, hycanthone and niridazole against Schistosoma mansoni in mice. Ann Trop Med Parasitol 65: 45-58.

Hillman GR, Senft AW 1975. Anticholinergic properties of the antischistosomal drug hycanthone. Am J Trop Med Hyg 24: 827-834.

Ismail M, Attia MM, Metwally AA, Farghaly AM, Bruce J, Benett J, Tao LF 1995. Praziquantel resistance to schistosomiasis mansoni in Egypt II - Response of Schistosoma mansoni isolates to different doses of praziquantel. Abstracts International Conference on Schistosomiasis, Cairo, Egypt, p. 166.

Jansma WB, Rogers SH, Liu CL, Bueding E 1977. Experimentally produced resistance to Schistosoma mansoni to hycanthone. Am J Trop Med Hyg 26: 926-936.

Kato K 1960. A correct application of the thick-smear technique with cellophane paper cover. A pamphlet 9 pp. In Y Komyia \& A Kobayashi, An evaluation of Kato Thick-smear. Jap J Med Sci Biol 19: 5964.

Katz N 1980. Resultados atuais na terapêutica clínica da esquistossomose mansoni. Rev Inst Med Trop S Paulo 22 (Suppl. IV): 123-133.

Katz N, Chaves A, Pellegrino J 1972. A simple device for quantitative stool thick-smear technique in schis- tosomiasis mansoni. Rev Inst Med Trop S Paulo 14: 397-400.

Katz N, Dias P, Araujo N, Souza CP 1973. Estudo de uma cepa de Schistosoma mansoni resistente a agentes esquistossomicidas. Rev Soc Bras Med Trop 7: 381-387.

Kemp HÁ, Hunter GW, Wilkin OP, Smalley H, Dashell MA 1956. Some ointments examined for protection against Schistosoma mansoni cercariae in preliminary tests. Militar Medicine 119: 1-10.

Kinoti GK 1987. The significance of variantion in the susceptibility of Schistosoma mansoni to the antischistosomal drug oxamniquine. Mem Inst Oswaldo Cruz 82 (Supl. IV) : 151-156.

Lambertucci JR, Greco DB, Pedroso ERP, Rocha MOC, Salazar HM, Lima DP 1990. Double blind trial with oxamniquine in chronic schistosomiasis mansoni. Trans $R$ Soc Trop Med Hyg 76: 751-755.

Meang FSW, Marshal I, Higgins M 1987. Oxamniquine resistance in S. mansoni. Fact or fiction? Am J Trop Med Parasitol 81: 337-339.

Pellegrino J, Katz N 1972. Experimental chemotherapy of schistosomiasis. V - Laboratory trials with UK 3883, a 2- aminomethyltetrahydroquinoline derivative. Rev Inst Med Trop S Paulo 14: 59-66.

Pessoa SB, Barros PR 1953. Notas sobre a epidemiologia da esquistossomose mansônica no Estado de Sergipe. Rev Med Cir São Paulo 13: 147-154.

Pica-Mattoccia L, Cioli D 1985. Studies on the mode of action of oxamniquine and related schistosomicidal drugs. Am J Trop Med Hyg 34: 112-118.

Pica-Mattoccia L, Dias LCS, Archer S 1989. Binding of oxamniquine to the DNA of schistosomes. Trans $R$ Soc Trop Med Hyg 83: 89-96.

Radke MG, Berrios-Duran LA, Morab K 1961. A perfusion procedure (Perf-o-suction) for recovery of Schistosoma mansoni. J Parasitol 47: 366-368. 